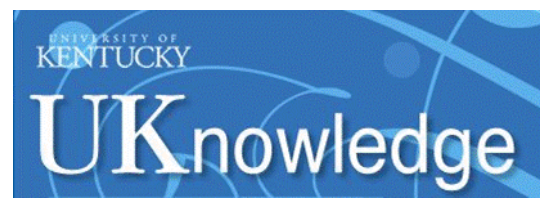

University of Kentucky

UKnowledge

\title{
Germination and Early Growth of Slickspot Peppergrass (Lepidium papilliferum) as Affected by Desert Soil Humic Acids
}

E. Loffredo

University of Bari, Italy

A. J. Palazzo

Cold Regions Research and Engineering Laboratory

N. Senesi

University of Bari, Italy

C. E. Clapp

U.S. Department of Agriculture

Follow this and additional works at: https://uknowledge.uky.edu/igc

Part of the Plant Sciences Commons, and the Soil Science Commons

This document is available at https://uknowledge.uky.edu/igc/21/13-1/10

The XXI International Grassland Congress / VIII International Rangeland Congress took place in Hohhot, China from June 29 through July 5, 2008.

Proceedings edited by Organizing Committee of 2008 IGC/IRC Conference

Published by Guangdong People's Publishing House

This Event is brought to you for free and open access by the Plant and Soil Sciences at UKnowledge. It has been accepted for inclusion in International Grassland Congress Proceedings by an authorized administrator of UKnowledge. For more information, please contact UKnowledge@lsv.uky.edu. 


\title{
Germination and early growth of slickspot peppergrass (Lepidium papilliferum) as affected by desert soil humic acids
}

\author{
E. Loffredo ${ }^{1}, A . J$. Palazzo ${ }^{2}, N$. Senesi $^{1}$ and C.E.Clapp ${ }^{3}$ \\ ${ }^{1}$ DIBCA .,University of Bari,70126-Bari,Italy.E-mail :senesi@agr.uniba.it 22ERDC-CRREL,Hanover,NH 03755- \\ $1290, U S A{ }^{3}$ USDA-A RS and University of Minnesota, St . Paul, MN 55108, USA
}

Key words : slickspot peppergrass, soil humic acids ,effects on germination ,effects on early grow th

Introduction Slickspot peppergrass (Lepidium papilliferum) is a reported rare" ephemeral endemic plant growing in the Southwest Idaho high desert, USA (Meyers et al 2005), whose seeds can remain dormant for several years. In 1999 this plant was listed as a species with high" threat magnitude, and imminent" immediacy of threat, under the Endangered Species Act . The name of the plant derives from its association with slickspots, which are small , crusted-or smooth-surfaced depressions in the soil that collect water within the region's sagebrush-steppe ecosystem, and form a unique microhabitat in western US basins such as the Idaho Snake River plain (Moseley 1994). The objective of this study was to evaluate the effects of soil humic acids on the germination and early grow th of slickspot peppergrass .

Materials and methods Three humic acids were isolated from the silt ( $\mathrm{HAs}$ ), vesicular ( $\mathrm{HAv}$ ) and clay ( $\mathrm{HAc}$ ) layers of an Idaho soil according to conventional standard procedures, and characterized for their chemical and physico-chemical properties by chemical methods and Fourier transform infrared and fluorescence spectroscopies. The three HAs were used at three concentrations $(10,50$ and $200 \mathrm{mg} / \mathrm{L})$ to measure their effects on seed germination of slickspot peppergrass in Petri dishes for 11 days, and subsequent seedling early grow th for 24 days. The experiments were conducted in four replicates in controlled conditions of temperature, humidity and illumination in a Fitotron chamber. Data obtained were subjected to statistical analysis by ANOVA. The possible relation of the effects measured with the compositional, structural and functional features of the HAs studied was also evaluated.

Results Statistical analyses of data show that (Figures 1 and 2) : (a) HAs at any concentration increases seedling primary root length and generally promotes early plant growth, but has a concentration-differentiated effect on the germination $\%$ and seedling primary shoot length; (b) HAv at any concentration exerts a positive effect on the germination $\%$ and root elongation but a depressing effect on shoot elongation; and (c) HAc promotes germination $\%$ and root elongation at the highest concentrations with no or depressing effect at the low est concentration, whereas the effect on shoot elongation is concentrationdependent .

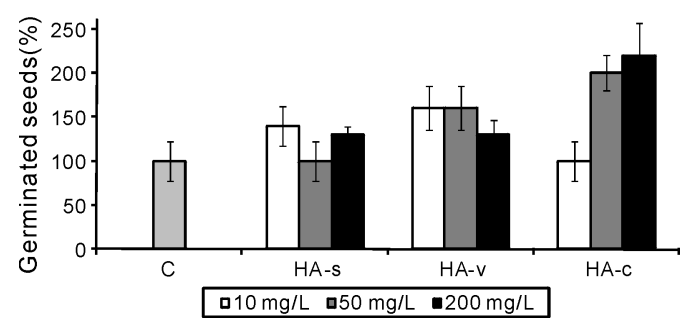

Figure 1 Effects of humic acids at different concentrations on the $\%$ of germinated seeds relative to the control treatment (100\%), measured after 11 days of germination. Vertical bars indicate the standard error $(n=4)$.

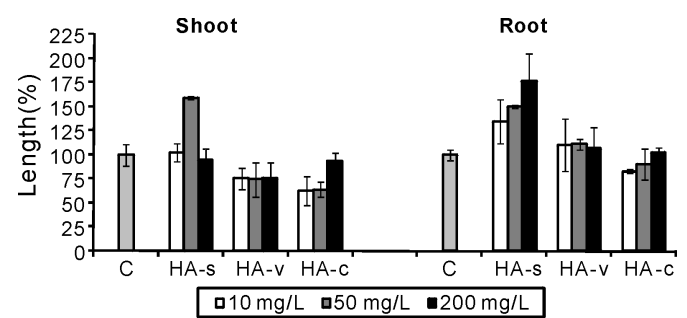

Figure 2 Effects of humic acids at different concentrations on the lengths of shoots and roots as percentages relative to the control treatment (100\%), measured after $24-d a y$ growth. Vertical bars indicate the standard error $(n=4)$.

Conclusion The effects of HAs on germination and early grow th of slickspot peppergrass can be related to their different $\mathrm{C}$, $\mathrm{H}$, $\mathrm{N}$, and $\mathrm{O}$ contents, $\mathrm{C} / \mathrm{N}$ ratio , aliphaticity, and amide, carboxylic and fluorescent groups contents .

\section{References}

Meyer SE, Quinney D, Weaver J (2005) A life hystory study of the Snake River Plains endemic Lepidum papilliferum (Brassicacee). Western North A merican Naturalist , $65,11-23$.

Moseley RK (1994) Report on the conservation status of Lepidum papilliferum. Status Survey Report. Idaho Department of Fish and Game, Boise, ID .

Acknowledgement This work was supported by the Research Contract n. N62558-03-M-0010 of the US Army European Research Office, London, England . 